\title{
Effects of mechanical cleaning by manual brushing and abrasive blasting on lime render coatings on Architectural Heritage
}

\author{
M.A. Iglesias-Campos $\bowtie$ \\ Universitat de Barcelona / GRAPAC/CETEC-patrimoni. Universitat Autònoma de Barcelona (Barcelona. Spain) \\ $\triangle$ manuel.iglesias@ub.edu
}

\begin{abstract}
This research studies the effects of mechanical cleaning by brushing and by abrasive blasting on the lime render coating of a façade. After analysing the properties of the material, the deposits to be removed and their possible influence on the treatment, different cleaning tests were made by manual brushing and by blasting with three varieties of abrasives at $45^{\circ}$ and $75^{\circ}$ angles, keeping the other parameters constant. Taking the restorer's perspective as a starting point, and in order to fulfil the practical requirements of an intervention, tests were evaluated with macro-photography, USB digital microscope and stereomicroscope with 3D visualization and measurement. From the results can be concluded that abrasives with low friability and greater grain size than the space between mortar aggregates blasted at a $75^{\circ}$ angle reduce the differential erosion compared to other abrasives; although manual brushing has less impact on the surface.
\end{abstract}

KEYWORDS: Cleaning; Manual brushing; Abrasive blasting; Lime render coating; Image analysis

Citation / Citar como: Iglesias-Campos, M.A. (2014) Effects of mechanical cleaning by manual brushing and abrasive blasting on lime render coatings on Architectural Heritage. Mater. Construcc. 64 [316], e039 http://dx.doi.org/10.3989/ mc.2014.08313.

RESUMEN: Efectos de la limpieza mecánica mediante cepillado manual y la limpieza mediante proyección de abrasivos en revestimientos de cal en Patrimonio Arquitectónico. En este trabajo se estudian los efectos de las limpiezas mecánicas con cepillado y con proyección de abrasivos sobre un revestimiento exterior de cal. Tras documentar las propiedades del material, de los depósitos superficiales y de su posible influencia en el tratamiento, se realizaron diferentes catas de limpieza con cepillado manual y con proyección de tres abrasivos con ángulos de $45^{\circ}$ y $75^{\circ}$ manteniendo constantes el resto de parámetros. Partiendo de la visión del conservadorrestaurador y de un carácter práctico según las necesidades reales de intervención, los ensayos se evaluaron con macrofotografía, microscopio digital USB y microscopio estereoscópico con visualización y medición en 3D. De los resultados se determina que los abrasivos de baja friabilidad y granulometría mayor que el espacio entre los áridos del mortero proyectados con un ángulo de $75^{\circ}$ reducen la erosión diferencial en comparación a otros abrasivos, aunque el cepillado manual altera menos la superficie.

PALABRAS CLAVE: Limpieza; Cepillado manual; Proyección de abrasivos; Enlucido de cal; Análisis de imagen

Copyright: (c) 2014 CSIC. This is an open-access article distributed under the terms of the Creative Commons Attribution-Non Commercial (by-nc) Spain 3.0 License.

\section{INTRODUCTION}

Mechanical cleaning is based on the application of energy with different tools to break and displace the bonding between surface deposits and substrate by impact, cutting or friction. Friction is considered the smoothest mechanism allowing greater control during treatment, although its effectiveness is usually restricted to thin and/or slightly compact surface deposits (1). 
Mechanical methods can be classified in manual or abrasive blasting depending on the tool used. In manual techniques, since antiquity, different tools have been used for reducing, working or cutting away surface deposits with low-level penetration in the substrate. One of the most common techniques is manual brushing for its friction mechanism. Abrasive blasting, based on the same cleaning processes but where the tools are abrasives, is a procedure used for years in Architectural Heritage for the same purpose, also aiming for predominance of friction over impact. Both techniques are mentioned in most general publications on building materials treatment (2-5), in descriptive articles (1) and in recommendations on standards for cleaning buildings (6-9).

As with any other cleaning technique, both treatments have some specific parameters. The correlation between material characteristics (heterogeneity, texture, cohesion and hardness, among others), surface deposits (mainly thickness and adhesion) and the tool or equipment used, will determine the final result and the predominant cleaning mechanism.

No documented references about parameters of manual techniques have been found. Probably because of the difficulty of measuring them, parameters are not usually included in studies and research although there are some recommendations about controlling them to remove deposits properly during cleaning (10). Their parameters can be determined from traditional use (pressure, angle, rate of movement, vibration, rotation, etc.), and from the tool (size, shape, composition, etc.) related to the work formula [ $W=F \times d=F \times d \times \cos \alpha]$ as a physical magnitude in classical mechanics, which posits a correspondence between energy or exerted force $[F]$, the displacement of surface deposits in this case $[d]$, and the angle formed by the force and the displacement vectors $[\cos \alpha]$.

Regarding abrasive blasting, there are different studies analysing the influence of its parameters (11-14), essentially similar to those of manual techniques. This cleaning technique is influenced by pressure, distance, angle, time, nozzle, particle-flow and specific abrasive properties (composition, size, specific weight, density, morphology, hardness, friability or toughness, etc.) because it is based on the kinetic energy formula $\left[E=1 / 2 m \times v^{2}\right]$, where $m$ is mass or abrasive; and $v$, velocity or pressure. Most of these parameters are not specified in studies. Pressure, the abrasive used, and usually its grain size are all that are mentioned, providing insufficient information to determine either how the cleaning is done or the extrapolation of results for similar situations.

To understand the influence of the different parameters in both techniques, it is necessary to recognize how the conservator-restorer performs the treatment. In manual techniques the restorer slides and/or applies force with the selected tool during a specific time on the surface deposit; in abrasive blasting he manually moves a nozzle that projects pressurised air and abrasive on the surface. In both techniques the continuous application of the manual tool or of the different particles, together with visual observation, determine when the required cleanliness level has been reached.

In both manual techniques and abrasive blasting, depending on different factors related with the technique, the material and the surface deposits, either a precise treatment can be achieved or the substrate can be damaged. Alterations, if any, are related to abrasion, impact or cutting mechanisms derived from the technique itself, and they appear as differential erosion, microcracks, loss of shine etc. (15), i.e. textural modifications favouring surface alteration and increasing the probability of greater re-soiling after treatment.

The aim of the study is to analyse and evaluate comparatively some poorly documented aspects of these cleaning processes using basic analysis techniques, readily available for the conservator-restorer responsible for cleaning, as well as investigating further mechanical effects of friction, seeking their effectiveness in frequent situations. Friction mechanism is very obvious in manual brushing but in abrasive blasting this effect is influenced by blasting angle and the abrasive's shape and grain size. As a parameter controlling friction mechanism, angle is not usually referred to except in some roughness tests (16), in some research papers (17) and in specific case studies $(11,13,18)$, where a $45^{\circ}$ angle is usually proposed as safer than $90^{\circ}$ angle; although recent studies on silicic sandstones have shown that the least aggressive angle is close to $75^{\circ}(19)$. Furthermore, although there are comparisons between products $(11-14,17,18)$ it is not usual to include morphology, grain size or friability when analysing their effects.

\section{MATERIAL AND METHODS}

Tests were made on different fragments of the lime render coating of a late nineteenth century façade in order to eliminate two layers of whitewash of different thickness and adherence. A basic preliminary study of the material and its surface deposits was made with magnifying optical techniques and chemical microanalysis reaction observed under stereomicroscope to determine quickly its generic composition, in order to propose trials with the data obtained.

The cleaning results were analysed by macrophotography and USB digital microscope to observe morphological surface changes and the degree of surface deposits removal because they are reasonably low-cost instruments for the restorer, allowing an evaluation that could be performed in situ. Subsequently, to investigate topographic changes significant for evaluating the cleaning effects (20), a stereomicroscope with $3 \mathrm{D}$ visualization and measurement was used in laboratory to analyse the 
surface and the primary profiles after treatment. Since it is a mechanical cleaning method, optical techniques facilitated enough information to take potential decisions in an actual intervention, providing relevant information about the studied parameters and their effects on the material without requiring more complex analytical techniques.

The devices used for studying the material and the cleaning evaluation were a USB digital microscope PCE-MM200 with $\times 10-200$ adjustable and a Leica M165C stereomicroscope with $\times 7.3-120$ adjustable with software Leica Stereo Explorer 3D visualizing and measurement.

\subsection{Lime render and whitewashes}

The fragments conserved a rough render coat (not considered in the study because it would be unaffected by cleaning) and a lime render with siliceous aggregates, between angular and rounded, predominant sizes of $250-500 \mu \mathrm{m}$ and mix ratio 1:4. The observation of the chemical microanalysis reaction with stereomicroscope revealed a carbonated composition of the lime render.

Cohesion between the binder and aggregates did not present significant conservation problems, the packing density ranged between loose and compact, and space between aggregates was $50-90 \mu \mathrm{m}$. The render had a uniform thickness, between 1.3 and $1.5 \mathrm{~mm}$; it was slightly rough, probably due to leaching of rain water, and maintained good adhesion to the rough render coat (Figure 1).

On the render there were two whitewashes: one on the surface in sienna colour, slightly powdery, with poor adherence to the lower layer, and 10-15 $\mu \mathrm{m}$ thick, and beneath it a white whitewash of 100-150 $\mu \mathrm{m}$ thick, of greater consistency, adherence and penetration in the rough render texture with which it could sometimes be confused. The observation of the chemical microanalysis reaction with stereomicroscope revealed a carbonated composition of the whitewashes.

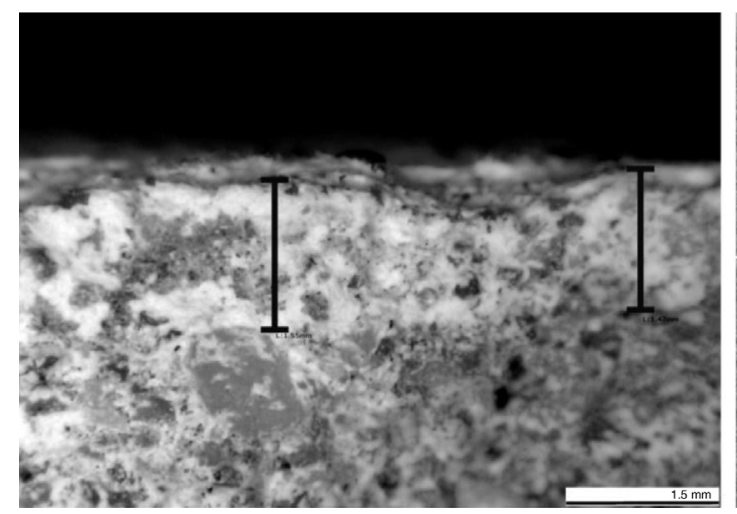

The distribution of these artificial deposits varied depending on the fragments. Some had the sienna whitewash directly on the render, others conserved isolated traces of white whitewash between the sienna and the render; and those on which the final trials were made had both whitewashes. It was not known if either of these whitewashes were applied originally, although the location of certain repairs seemed to suggest they were subsequent.

In this case, the properties most likely to increase the probability of surface damage by manual brushing or abrasive blasting mechanical action are: low substrate mineral hardness, difference in size and hardness between binder and aggregates, mix ratio and the resulting packing density, surface texture and difference of adherence and hardness between the whitewash layers (Table 1).

\subsection{Methods}

The aim of the tests was to check the possibility of removing the two whitewashes, layer by layer, by manual brushing and abrasive blasting without damaging the render surface, taking into account that the original surface was the rough texture of the mortar.

After initial trials on small fragments, tests were made on the larger fragment $(17 \times 11 \times 2.5 \mathrm{~cm})$ placed vertically to reproduce its position in a façade. Different surfaces, approximately $54 \mathrm{~cm}^{2}$, were generated subdividing the fragment longitudinally to verify the feasibility of removing the sienna whitewash while maintaining the white one, and subsequently removing the white whitewash without damage to the render surface. The fragment was also subdivided transversely to compare the effects of changing the angle during the abrasive blasting (Figure 1). The area was delimited with special adhesive plastic tape for glazing to provide a reference to the initial situation. Cleaning was made without shaping the ends of the treatment area, superimposing it on the protective tape.

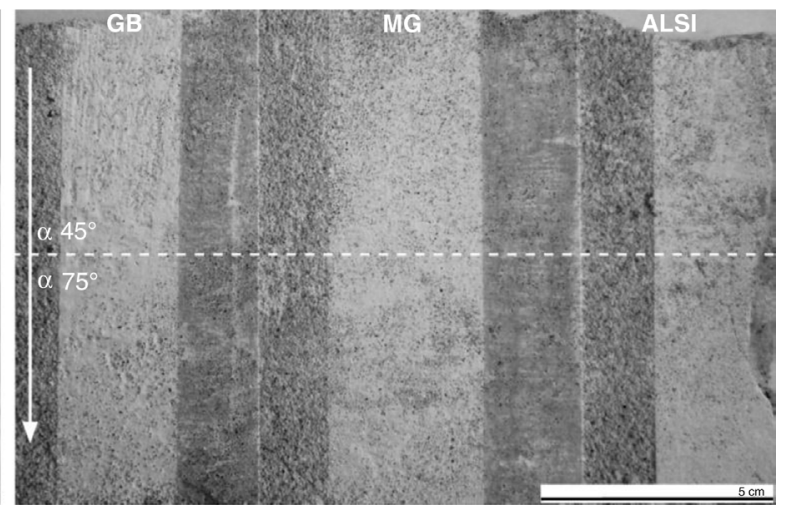

FIGURE 1. Render and whitewashes section. USB digital microscope image (left). Surface render during cleaning treatment [GB: glass beads, MG: micronized glass, ALSI: aluminium silicate] (right). 
TABLE 1. Substrate parameters and possible influence on cleaning

\begin{tabular}{|c|c|c|c|}
\hline Layer & Properties & & Influence \\
\hline \multirow[t]{5}{*}{ Whitewash } & Hardness & \pm 3 Mohs & Easy to clean \\
\hline & Thickness & $110-145 \mu \mathrm{m}$ & Uniformity in cleaning time due to deposit thickness homogeneity \\
\hline & Adherence & $\begin{array}{l}\text { Uneven among whitewashes } \\
\text { Adherent with surface render }\end{array}$ & $\begin{array}{l}\text { Variability in cleaning time } \\
\text { Control time needed to remove the last layer }\end{array}$ \\
\hline & Texture & $\begin{array}{l}\text { Powdered (sienna) } \\
\text { Compact (white) }\end{array}$ & Significant difference in behaviour during cleaning \\
\hline & Composition & $\begin{array}{l}\text { Lime + pigments (sienna) } \\
\text { Lime (white) }\end{array}$ & $\begin{array}{l}\text { Uniform treatment is possible because layers are similar in } \\
\text { composition }\end{array}$ \\
\hline \multirow[t]{4}{*}{ Render } & $\begin{array}{l}\text { Mineralogy } \\
\text { and hardness }\end{array}$ & $\begin{array}{l}\text { Binder ( } \pm 3 \text { Mohs) } \\
\text { Siliceous aggregates ( } \pm 6-7 \text { Mohs) } \\
\text { sized } 250-500 \mu \mathrm{m} \\
\text { Mix ratio } 1: 4\end{array}$ & $\begin{array}{l}\text { Binder with lower hardness compared to tested abrasives or } \\
\text { synthetic brush bristles } \\
\text { Hardness average of aggregates similar to the abrasives used or } \\
\text { greater than synthetic brush bristles } \\
\text { Main alterability due to mineral hardness variability and packing } \\
\text { density (related to the proportion of the mixture) }\end{array}$ \\
\hline & Porosity & $\pm 15-20 \%$ & Difficulty in cleaning \\
\hline & Texture & Cemented & Difficulty in cleaning \\
\hline & Surface texture & Rough & Difficulty in cleaning \\
\hline
\end{tabular}

For abrasive cleaning a suction gun with $3 \mathrm{~mm}$ straight nozzle, $150 \mathrm{l} / \mathrm{min}$ flow compressor and dehumidifier filter were used. Despite being a soft substrate, 2 bars of pressure on the manometer was selected, since the suction equipment consumes about half of the energy to absorb the abrasive and the rest in blasting it, an output pressure of approximately 1 bar could be achieved (minimum blast pressure of most commercial equipment for sale or rent).

Three of the most common abrasives for these treatments were selected: glass beads $75-150 \mu \mathrm{m}$, micronized glass $100-250 \mu \mathrm{m}$, and aluminium silicate $80-160 \mu \mathrm{m}$. These abrasives, the most similar in grain size among the commercially available, despite having similar hardness, shapes and friability rates, are different and may influence final cleaning results (Figure 2, Table 2).

On every surface $45^{\circ}$ and $75^{\circ}$ angles were used. For distance, to unify the real measurement from the nozzle end with the selected angles, $10 \mathrm{~cm}$ was determined; this distance corresponds to the hypotenuse of the triangle formed between nozzle and surface with a distance of $7.1 \mathrm{~cm}$ at $45^{\circ}$ and $9.7 \mathrm{~cm}$ at $75^{\circ}$. This distance was selected as one of the most usual ones when cleaning smooth surfaces with suction gun or microblaster. A reference rail was used to maintain distance and angle.

Samples were covered with a metal plate until a uniform and constant flow projection was reached to control as far as possible the homogeneity of this manual treatment. At this moment the trial was initiated. This procedure was necessary because when the switch is activated at first, flow is not constant depending on pressure, hose length and abrasive characteristics, among others. The same protective device was used to prevent the abrasive that continues to flow after releasing the switch control impacting with the surface at the end of the set time. After cleaning, each surface test was covered with paper to prevent visual and time comparisons that could influence the restorer's treatment.

For manual cleaning a soft toothbrush of synthetic bristles $220 \mu \mathrm{m}$ in diameter and $1 \mathrm{~cm}$ long grouped in tufts of $2 \mathrm{~mm}$ diameter, and a rectangular surface area of $3 \mathrm{~cm}^{2}$ was used. It was moved
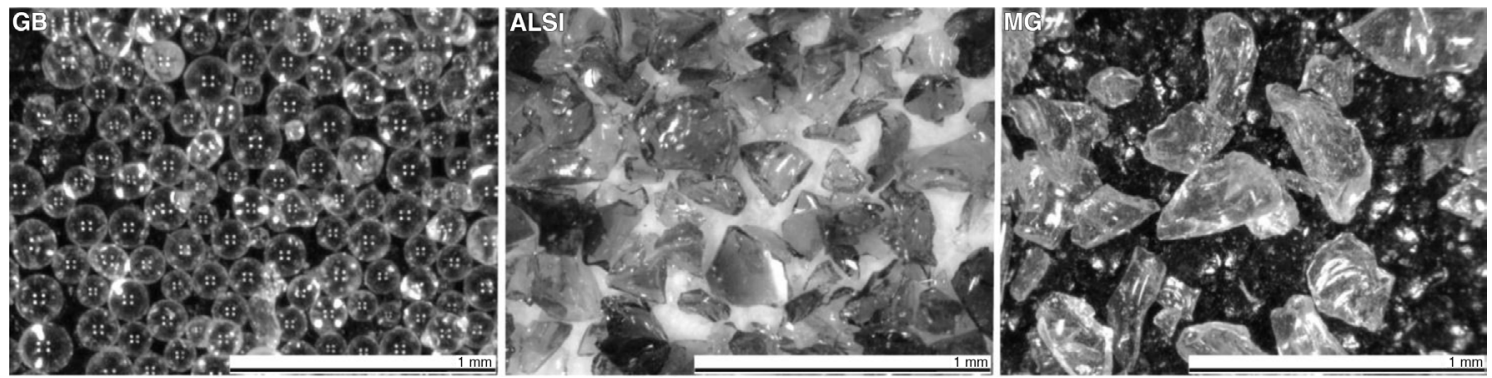

FIGURE 2. Abrasives used in the trials. USB digital microscope image [GB: glass beads, MG: micronized glass, ALSI: aluminium silicate]. 
TABLE 2. Characteristics of the abrasives used in the trials

\begin{tabular}{llcrc}
\hline Abrasive & \multicolumn{1}{c}{ Morphology } & Grain size $(\boldsymbol{\mu m})$ & Hardness $($ Mohs) & Friability \\
\hline Glass beads & Spherical & $75-150$ & $6-7$ & Low \\
Micronized glass & Irregular shapes, cubical and angular & $100-250$ & $6-7$ & Low \\
Aluminium silicate & Irregular shapes, laminar and ridged & $80-160$ & 7 & Medium \\
\hline
\end{tabular}

longitudinally, hardly exerting pressure at an angle of $0^{\circ}$. Of the parameters that influence this manual treatment, only the angle, the tool material and its size could be defined.

During both tests an assistant was timing the duration of the treatments and protecting and uncovering the surface in the abrasive blasting. In time measurements a slight margin of error must be taken into account because it was not an automated system, and so time must be understood as a reference to the speed of cleaning.

\section{RESULTS AND DISCUSSION}

Analysing the removal of the sienna whitewash and evaluating the white whitewash as the final treatment surface, changing the blasting angle or the abrasive was not found to make a substantial difference. The low thickness of sienna whitewash and its poor adhesion to the white one required a very fast nozzle movement and therefore cleaning was performed with hardly any significant interaction between surface and particles. Air and a small quantity of abrasive eliminated this artificial deposit (time $\pm 2 \mathrm{~s}$ ). Nevertheless, the white whitewash surface is slightly lowered, visibly and to the touch. With manual brushing the sienna whitewash is also easily removed (time $\pm 3 \mathrm{~s}$ ) and, although it leaves more residues, the lowering produced on the white whitewash is less than with abrasive blasting.

Studying the removal of white whitewash and analysing the lime render as the final treatment surface, results with abrasive blasting were different and seem to be related to the effects of the angle and the characteristics of the abrasives used.

Regarding the angle, and irrespective of the abrasive, differences can be distinguished in the alteration produced. Surfaces treated at $45^{\circ}$ show differential erosion which highlights the aggregates. The low mineral hardness of lime compared to the abrasives used, 3 and 6-7 Mohs respectively, suggests that, even with low pressure and significant distance, the binder is eroded by the friction mechanism. Aggregates, having a similar hardness to the abrasive, are not altered. Furthermore, in some cases this erosion provokes detachment of aggregates and significant surface recess of $250-550 \mu \mathrm{m}$ (Figure 3).

Tests at $75^{\circ}$, reducing the friction mechanism and slightly increasing the impact, also modify surface texture, leaving a less eroded surface with smaller loss of aggregates (Figure 4).

Although they concern different materials, pressures higher than those used here, and without references to angle variations, these observations are consistent with some studies of abrasive blasting on sandstones with carbonated cement. In those studies, it was observed by SEM and roughness measurements that cement is preferentially eroded more than other minerals, resulting in greater roughness when it was unevenly distributed (21).

With both angles used, individualized longitudinal marks to the blasting trajectory can be distinguished. Aggregates channel the abrasive distribution to the space filled with a binder of lower hardness. But compared to this general lime erosion, it is observed that, according to the projection trajectory, the binder does not suffer erosion on the rear side of the aggregates (Figures 3 and 4). Although they concern different materials, the data are consistent with studies on granite that report limited alteration of softer minerals which are protected by differences in the relief and greater hardness of the contiguous minerals (17) or studies on siliceous sandstone (19).

Therefore, as in natural detritic materials (19), an angle of $45^{\circ}$ causes greater alteration and further modifies the surface by differential erosion of the softer components than the $75^{\circ}$ angle.

Analysing the influence of the abrasive regardless of the angle, no significant changes were observed between surfaces but the area treated with micronized glass is less altered when observed in detail (Figures 4 and 5). This seems mainly related to its larger particle size compared with the other abrasives used, and indirectly to its lower friability. The larger grain size of the micronized glass $(100-250 \mu \mathrm{m})$ in relation to the space between the aggregates $(50-100 \mu \mathrm{m})$ reduces the possibility of its penetration, and thus the erosion of the binder. Moreover, its smaller friability index reduces its breakage during transport through the hose and nozzle, and the particles reach the surface closer to the nominal sizes than other abrasives used. Thus, the overall recess caused by micronized glass is less than with other abrasives and primary profiles of analysed areas show lower penetration of the product between the spaces occupied by the binder. A similar effect, although in sedimentary rocks, is described evaluating two grain sizes of the same 


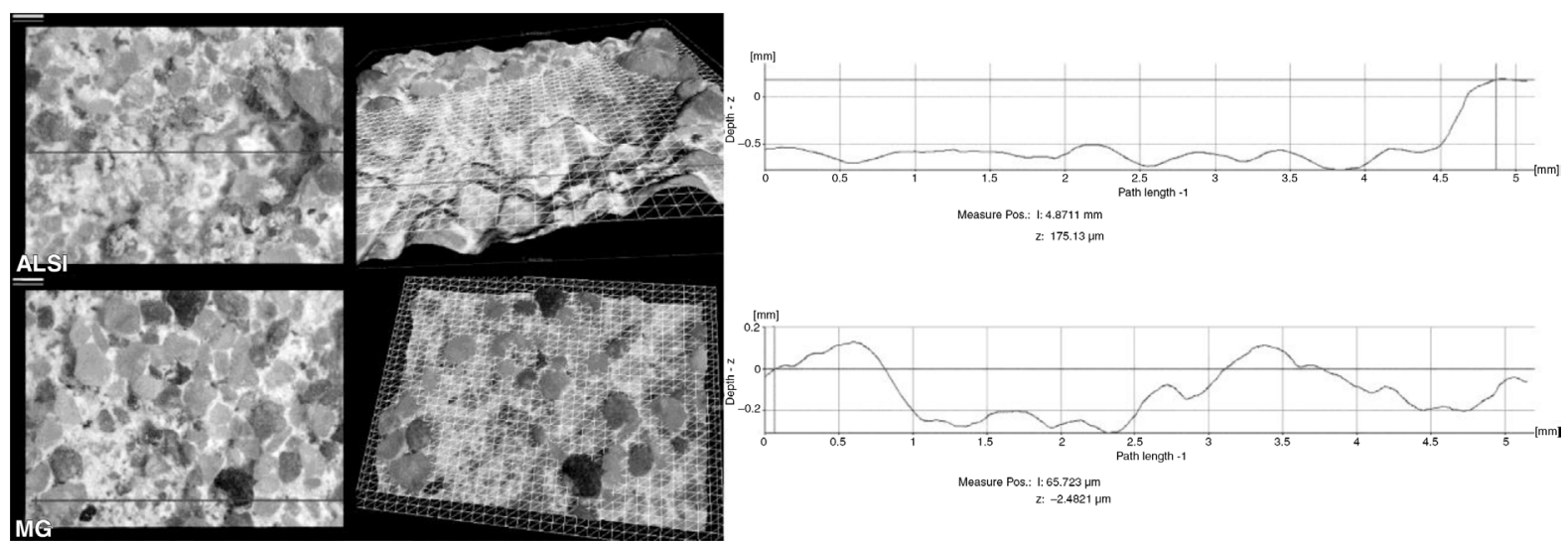

FIgURE 3. Surface render after blasting at $45^{\circ}$ angle with aluminium silicate [ALSI] and micronized glass [MG]. Surface and cutoff (left), reticulated area of original render level (centre) and primary profiles of analysed cutoffs.

Stereomicroscope with 3D visualizing and measuring image. Scale $500 \mu \mathrm{m}$.
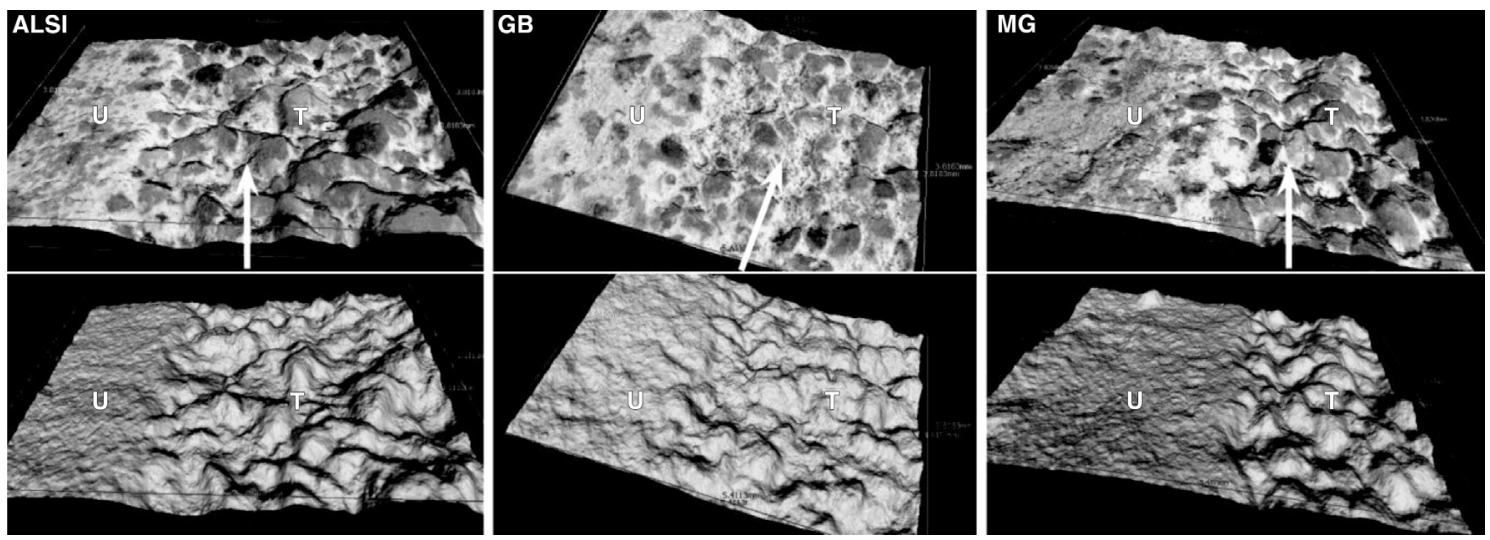

FIGURE 4. Surface render after blasting at $75^{\circ}$ angle with aluminium silicate [ALSI], glass beads [GB] and micronized glass $[\mathrm{MG}]$ (arrow: blasting direction). Surface untreated $[\mathrm{U}]$ and treated $[\mathrm{T}]$ (top) and surface uniform in texture (bottom). Stereomicroscope with 3D visualizing and measuring image.
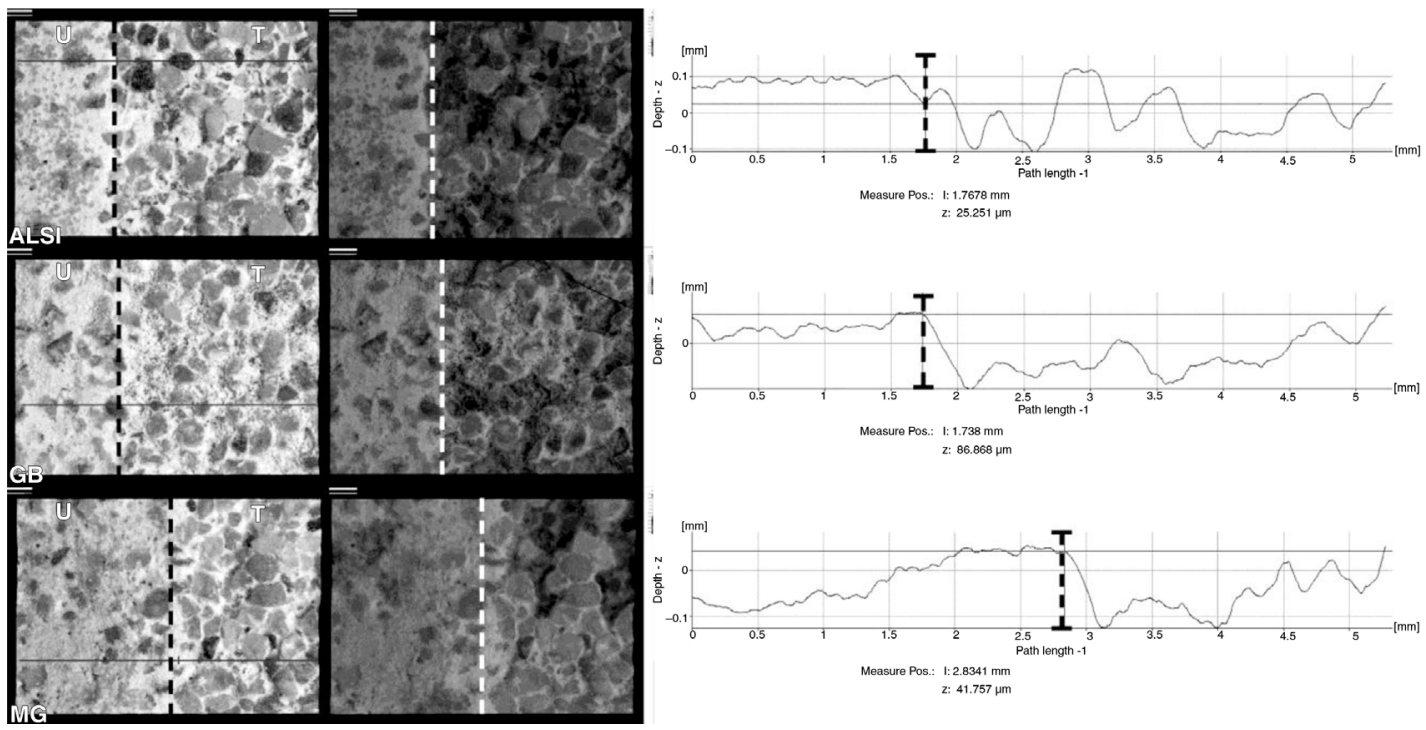

FIGURE 5. Comparison of untreated [U] and treated [T] surfaces at $75^{\circ}$ angle with aluminium silicate [ALSI] glass beads $[\mathrm{GB}]$ and micronized glass $[\mathrm{MG}]$. Surface and cutoff (left), surface texture analysis (center) and primary profiles of analysed cutoffs (right). Stereomicroscope with 3D visualizing and measuring image. Scale $500 \mu \mathrm{m}$. 

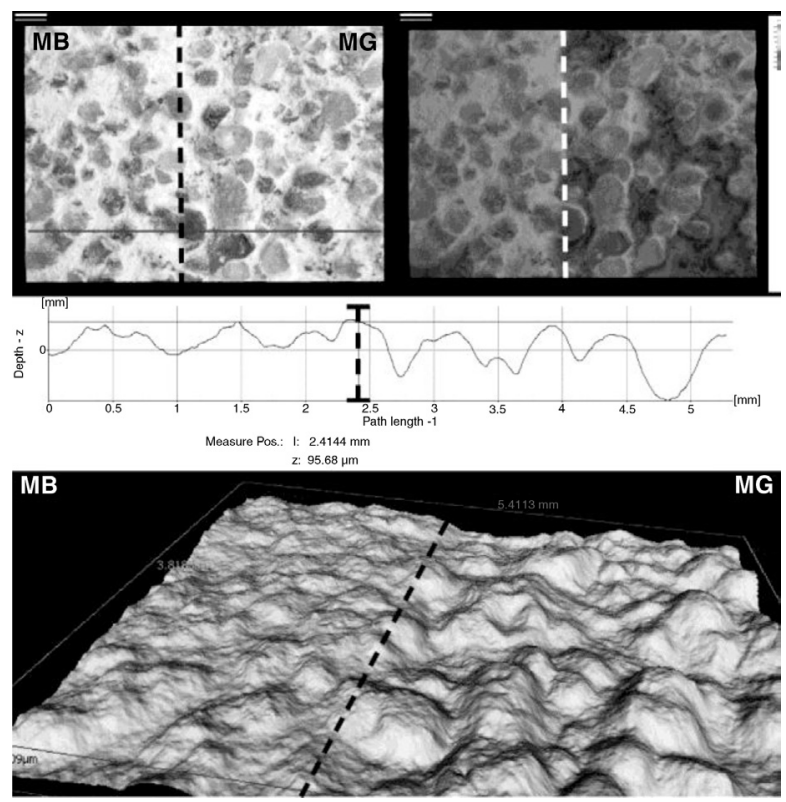

FIGURE 6. Comparative images of treated surface by manual brushing $[\mathrm{MB}]$ and abrasive blasting at $75^{\circ}$ angle with micronized glass [MG]. Surface and cutoff (top left) and texture surface analysis (top right). Scale $500 \mu \mathrm{m}$. Primary profile of analysed cutoffs (centre). Analysed surface in uniform texture (bottom).

Stereomicroscope with $3 \mathrm{D}$ visualizing and measuring image.

abrasive and observing that the larger size has less penetration between the calcite cement of the studied materials (17).

In this situation, therefore, the smaller size and the greater friability of glass beads and aluminium silicate enable their particles to be easily introduced between the intergranular space and favour differential erosion. As no differences have been observed in the surface morphology related to abrasive or time spent (time $\pm 3 \mathrm{~s}$ in all tests) the data seems to support the proposal of grain size as a prominent factor in alteration.

Regarding manual brushing, the consistency of white whitewash makes their removal difficult by exclusively manual mechanical treatment. Therefore bristles were wetted with deionised water using the same parameters as in dry cleaning. The results were similar to the abrasive blasting regarding alteration but with a minor recess of the binder. Brushing also produces differential erosions similar to any of the abrasives by the displacement of the bristles between the aggregates, and thus a lowering of the lime (Figure 6). This erosion may have been facilitated by the softening produced by the small amount of water used, as well as the added friction of surface whitewash particles removed during manual movement of the brush, which increased its erosive action. However, the surface finishing is different, especially in the degree of whitewash removal. Although it has been eliminated, the aggregate surface presents a less clear aspect because some residues are not fully removed (Figure 7). The time used to clean the surface was also greater $( \pm 5 \mathrm{~s})$.

\section{CONCLUSIONS}

As has been verified, mechanical cleaning by manual brushing or abrasive blasting on lime render coatings produces differential erosion by a friction mechanism modifying its surface roughness; the binder is eroded while aggregates are not altered.

In abrasive blasting, maintaining parameters constant and using an abrasive with low friability and greater grain size than the space between
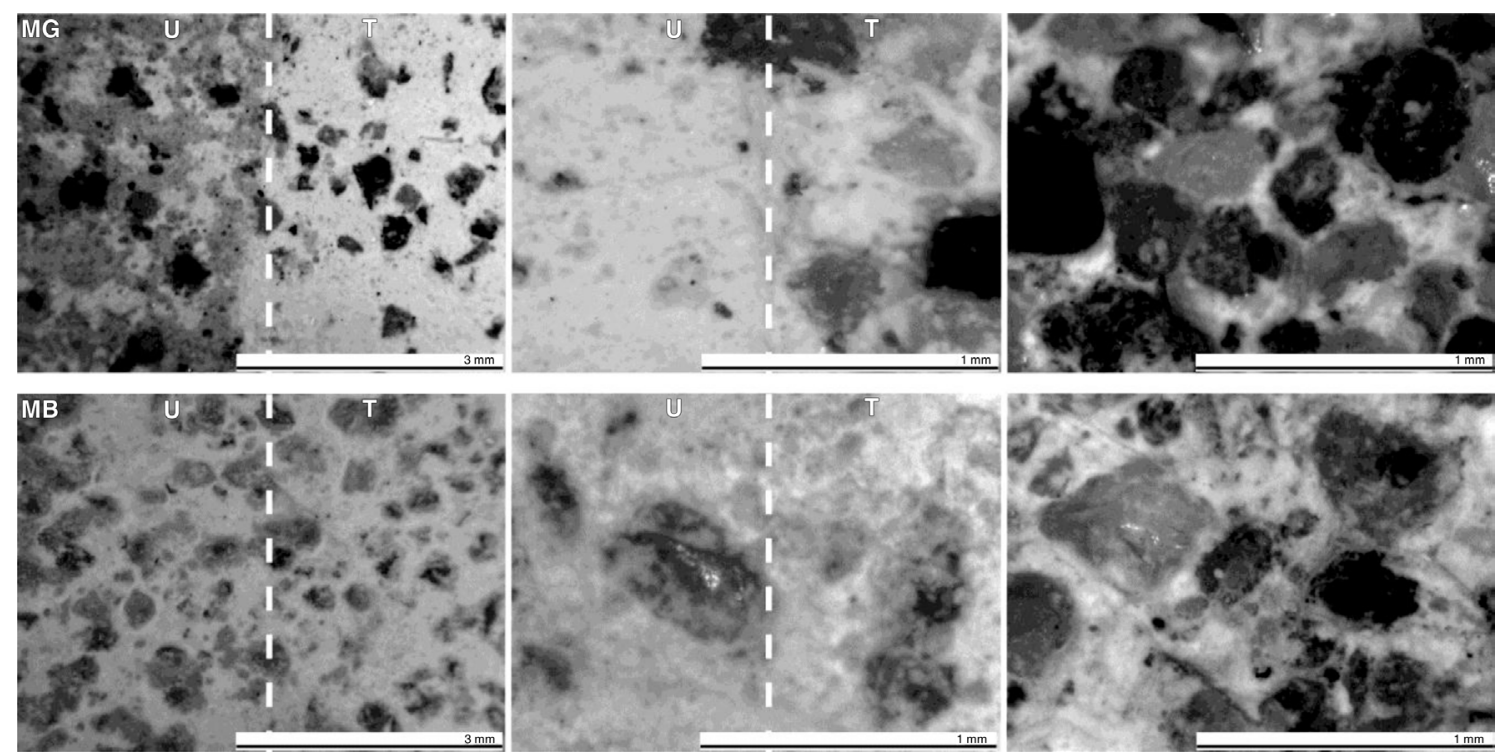

FiguRE 7. Comparative images of blasted surface with micronized glass [MG] at $75^{\circ}$ angle and by manual brushing [MB] Untreated $[\mathrm{U}]$ and treated $[\mathrm{T}]$ surface (left and centre) and detail of the treated area (right). USB digital microscope image. 
mortar aggregates blasted at a $75^{\circ}$ angle, differential erosion is reduced in comparison to abrasives which are more friable and/or smaller, because they penetrate less in the binder area.

Nevertheless, manual brushing is the mechanical technique which least alters the surface even though the time spent on cleaning is slightly longer.

Evaluation using simple techniques which allow comparative optical observation at different scales has been sufficient for a study according to the needs of an actual intervention. The surface analysis with macrophotography and USB digital microscope in situ and stereomicroscope with $3 \mathrm{D}$ visualization and measurement in laboratory have provided enough information to assess the effects of these mechanical cleanings. Direct observation and images obtained have clarified the results because surface deposits are essentially perceived as a modification of visual parameters of what is considered an original and clean surface.

Even though tests were made on a lime render coating, the treatment effects could be extrapolated to a cleaning affecting mortar joints of similar composition in a wall.

\section{ACKNOWLEDGEMENTS}

To Dr. Salvador García Fortes (Secció de Conservació-Restauració. Facultat de Belles Arts. Universitat de Barcelona) and Dr. José Luis Prada Pérez (GRAPAC/CETEC-patrimoni) for their comments and suggestions. To Dr. Salvador Borrós and María José Alcayde (Grupo de Ingenieria de Materiales, Institut Químic de Sarrià, Universitat Ramon Llull) for facilitating the use of 3D stereomicroscope in this study.

\section{REFERENCES}

1. Iglesias Campos, M. (2010) Métodos mecánicos para la limpieza de materiales constructivos: proyección de abrasivos a baja presión. In Gisbert Aguilar, J. (ed.). La tecnología láser y otros métodos de limpieza y restauración de materiales pétreos. Documentos para la caracterización y restauración del patrimonio histórico. Cuadernos Arbotante [1], Libros Pórtico, Zaragoza, 29-43.

2. Lazzarini, L.; Laurenzi Tabasso, M. (1986) Il restauro della pietra, 318, CEDAM, Padova.

3. Ashurst, N. (1994) Cleaning historic buildings. Vol. 2: Cleaning materials and processes, 258, Donhead Publishing, London

4. Esbert, R.M.; Ordaz, J.; Alonso, F.J.; Montoto, M. (1997) Manual de diagnosis y tratamiento de materiales pétreos y cerámicos. Manuals de Diagnosi, [5], 139, Barcelona, Col-legi d'Aparelladors i Arquitectes Tècnics de Barcelona.

5. Vergès-Belmin, V.; Bromblet, P. (2000), Le nettoyage de la pierre. Monumental. Revue scientifique et technique des Monuments Historiques, 246-248.
6. Commissione Normal. (1986) CNR-ICR. Normal 20/85. Interventi conservativi: progettazzione, esecuzione e valutazione preventiva.

7. BS 8221-1:2000. (2000) Code of practice for cleaning and surface repair of buildings. Part 1: Cleaning of natural stones, brick, terracotta and concrete.

8. ASTM International: E1857-97 (2004). Standard guide for selection of cleaning techniques for masonry, concrete and stucco surfaces.

9. AENOR: UNE 41806-3:2009 IN. (2009) Conservación de edificios. Limpieza de elementos constructivos. Parte 3: Técnicas de limpieza mecánica

10. AA.VV. (1992) Cleaning. Science for conservators. 2, 136, Routledge, London.

11. Iglesias, M.; Gea, B.; Prada, J.L.; Guasch, N. (2006) Lowpressure abrasive cleaning of historic building materials. In Fort, R.; Álvarez de Buergo, M.; Gómez Heras, M. \& Vazquez-Calvo, C. (eds.). Proceedings of the International Heritage, Weathering and Conservation Conference ( $H W C$ 2006), 21-24 June 2006, Madrid, Spain,Taylor \& Francis, London, 681-686.

12. Alonso, F.J.; Esbert, R.M.; Ordaz, J.; Valdeón, L.; Rojo, A.; Mateos, F. (2007) El claustro de la catedral de Oviedo: conservación de la piedra. In Restauradores sin Fronteras e Instituto de Geología Económica (CSIC-UCM) (ed.). Ciencia y tecnología para una conservación sostenible del Patrimonio Pétreo, Boceto, Madrid, 13-21.

13. Iglesias, M.; Prada, J.L.; Guasch, N. (2008). Technique for cleaning Tarragona Miocene age dolomitizied silty limestone, altered by urban pollution. Mater. Construc. 58, [289-290], 247-262. http://dx.doi.org/10.3989/mc.2008.v58.i289-290.87.

14. Perez-Monserrat, E.M.; Varas, M.J.; Fort, R.; de Buergo, M.A. (2011) Assessment of different methods for cleaning the limestone facades of the former workers Hospital of Madrid, Spain. Stud. Conserv. 56, [4], 298-313. http:// dx.doi.org/10.1179/204705811X13159282692969.

15. Young, M.E.; Urquhart, D.C.M.; Laing, R.A. (2003) Maintenance and repair issues for stone cleaned sandstone and granite building façades. Build. Environ. 38, [9-10], 11251131. http://dx.doi.org/10.1016/S0360-1323(03)00084-2

16. Grissom, C.A.; Charola, A.E.; Wachowiak, M.J. (2000) Measuring surface roughness on stone: back to basics. Stud. Conserv. 45, [2], 73-84. http://dx.doi.org/10.1179/ sic.2000.45.2.73.

17. Blanco Domínguez, M. (2010) Aplicación del láser y de la proyección de abrasivos en rocas ornamentales y de cantería aragonesas. Doctoral Thesis, Universidad de Zaragoza.

18. Iglesias, M. (2003) Un ensayo de limpieza de superficies delicadas por proyección de abrasivos a baja presión. $A K O B E$. Restauración y conservación de bienes culturales, [4], 13-16.

19. Iglesias-Campos, M.A.; García Fortes, S.; Prada Pérez, J.L. (2014) Influence of projection angle in sandblasting cleaning on detrictic stone materials in Architectural Heritage. Mater. Construc. 64 [314] e021. http://dx.doi.org/10.3989/ mc.2014.02113

20. Vazquez-Calvo, C.; Alvarez de Buergo, M.; Fort, R.; VarasMuriel, M.J. (2012) The measurement of surface roughness to determine the suitability of different methods for stone cleaning. J. Geophys. Eng. 9, S108-S117. http://dx.doi. org/10.1088/1742-2132/9/4/S108.

21. Young, M.E.; Urquhart, D.C.M. (1992) Abrasive cleaning of sandstone buildings and monuments: an experimental investigation. In Webster, R.G.M. (ed.). Stone cleaning and the nature, soiling and decay mechanisms of stone. Proceedings of the International Conference held in Edinburgh, UK, 14-16 April 1992. Donhead Publishing, London, 128-140. 